\title{
РЕМОДЕЛЮВАННЯ ЛІВОГО ШЛУНОЧКА У ПАЦІЄНТІВ З ПАРОКСИЗМАЛЬНОЮ ФІБРИЛЯЦІЄЮ ПЕРЕДСЕРДЬ ПРИ ПОЛІМОРФІЗМАХ ГЕНІВ РЕНІН-АНГІОТЕНЗИН-АЛЬДОСТЕРОНОВОЇ СИСТЕМИ
}

\author{
๑І. М. Фуштей, С. Г. Подлужний, Є. В. Сідь \\ Державний заклад “Запорізька медична академія післядипломної освіти Міністерства охорони \\ здоров'я України"
}

РЕЗЮМЕ. Сучасними важливими медико-соціальними проблемами у світі $є$ гіпертонічна хвороба (ГХ), ішемічна хвороба серця (IXC) та фібриляція передсердь (ФП). Виникненню аритмій може сприяти поєднання певних поліморфізмів генів, особливо актуальним $\epsilon$ вивчення ролі генів ренін-ангіотензин-альдостеронової системи (РАAC), оскільки у даний час, саме ії роль, у патогенезі ФП поєднаної з ГХ визначається як провідна. У даний час $\epsilon$ обмежена кількість даних про зв' язок гіпертрофії лівого шлуночка у пацієнтів з коморбідною патологією, що вказує на необхідність визначення популяційних особливостей при вивченні ролі поліморфізмів генів у розвитку мультифакторних захворювань таких, як IXC та ГХ та їх ускладнень, що викликає великий практичний інтерес.

Мета - визначити особливості ремоделювання лівого шлуночка у пацієнтів з пароксизмальною фібриляцією передсердь при поліморфізмах генів ренін-ангіотензин-альдостеронової системи.

Матеріали і методи. Для досягнення мети було проведено проспективне, відкрите порівняльне дослідження на базі комунального некомерційного підприємства «Міська лікарня № 10» Запорізької міської ради. Вибірку пацієнтів проводили в період з 2014 по 2019 рр. Результати дослідження базуються на даних комплексного обстеження і динамічного спостереження за 176 хворими на пароксизмальну ФП на тлі IXC з гіпертонічною хворобою, з них було 98 осіб із міста Запоріжжя та 78 - із сільської місцевості. Розподіл хворих на групи проводили після встановлення відповідності хворих щодо критеріїв включення/виключення дослідження залежно від комбінації генотипу поліморфізмів генів. Усім обстеженим було виконано ехокардіографічне дослідження, визначення поліморфізму генів.

Отримані результати. Було виявлено, що генетичні поліморфізми ренін-ангіотензин-альдостеронової системи можуть впливати на вираженість патологічних змін у хворих на пароксизмальну ФП на тлі IXС з гіпертонічною хворобою. Визначено, що поліморфізм Т174М гена ангіотензиногену впливає на показники ремоделювання лівого шлуночка. У пацієнтів, що мали алельний ген М, індекс маси міокарда лівого шлуночка був достовірно вище. Дослідження поліморфізму A1166C гена AGTR1 дозволяє прогнозувати ризик виникнення несприятливого концентричного ремоделювання лівого шлуночка, при наявності у хворого алельного гену С збільшується ризик у 2,03 раза.

Висновки. Таким чином, при дослідженні впливу даних поліморфізмів на діяльність серцево-судинної системи слід враховувати генетичні особливості окремих етносів і популяцій. Отримані нами результати дозволяють вважати поліморфізми генів додатковим фактором прогнозу формування неадекватної маси лівого шлуночка, що веде до його несприятливого ремоделювання.

КлючовІ СловА: ремоделювання серця; ренін-ангіотензин-альдостеронова система; ген; фібриляція передсердь; ехокардіографія.

Вступ. Сучасними важливими медико-соціальними проблемами у світі є гіпертонічна хвороба (ГX), ішемічна хвороба серця (IXC) та фібриляція передсердь (ФП). Поширеність ФП у популяції дорослого населення становить $2 \%$ для тих кому до 65 років і $9 \%$ для тих, хто старше 65 річного віку. У даний час ФП розглядається як потенційно летальна аритмія, враховуючи широкий спектр ії негативних наслідків, пов'язаних перш за все 3 розвитком тромбоемболічних ускладнень $[1,2]$.

Фібриляція передсердь це багатофакторне захворювання, в розвитку якого мають значення вік пацієнта, артеріальна гіпертензія, фактори зовнішнього середовища і генетична схильність. До третини пацієнтів з даною аритмією мають загальні генетичні варіанти, що призводять до ФП, хоча і з відносно низьким додатковим ризиком. Ризик розвитку збільшується у тих, хто має в анамнезі має хоча 6 одного з батьків з даною аритмією [3-5].

Виникненню аритмій може сприяти поєднання певних поліморфізмів генів, особливо актуальним $\epsilon$ вивчення ролі генів ренін-ангіотензинальдостеронової системи (РААС), оскільки у даний час, саме її роль, у патогенезі ФП поєднаної з ГХ визначається як провідна. Останні дані підтверджують, що саме активація РААС відіграє важливу роль у розвитку та збереженні ФП у паці$\epsilon$ нтів, які мають ГX [6].

У даний час найбільш активно вивчаються поліморфізми PAAC A1166C гена AGTR1, який кодує рецептор ангіотензину II I типу та T174М гена AGT, що кодує білок ангіотензиноген. У ряді досліджень виявлено зв' язок між поліморфізмами генів (AGTR1 і AGT), що кодують компоненти РAAC з ГХ та ФП. Крім того, виявлено асоціації полімор- 
Огляди літератури, оригінальні дослідження, погляд на проблему, випадок з практики, короткі повідомлення

фізмів генів РААС з розвитком гіпертрофії лівого шлуночка (ГЛШ) [7-9].

У даний час $\epsilon$ обмежена кількість даних про зв'язок ГЛШ у пацієнтів з коморбідною патологією, що вказує на необхідність визначення популяційних особливостей при вивченні ролі поліморфізмів генів у розвитку мультифакторних захворювань таких, як IXC та ГХ та їх ускладнень [10]. Ці дослідження викликають великий практичний інтерес, оскільки встановлення зв'язку генетичних факторів зі структурно-функціональних змінами серця, дозволить якомога раніше визначати ризик розвитку несприятливого ремоделювання лівого шлуночка, у конкретній популяції хворих, що визначило мету даної роботи.

Мета дослідження. Визначити особливості ремоделювання лівого шлуночка у пацієнтів з пароксизмальною фібриляцією передсердь при поліморфізмах генів ренін-ангіотензин-альдостеронової системи.

Матеріал та методи дослідження. Для досягнення мети було проведено проспективне, відкрите порівняльне дослідження на базі комунального некомерційного підприємства «Міська лікарня № 10» Запорізької міської ради. Вибірку пацієнтів проводили в період з 2014 по 2019 рр. Результати дослідження базуються на даних комплексного обстеження і динамічного спостереження за 176 хворими на пароксизмальну ФП на тлі IXC з гіпертонічною хворобою, з них було 98 осіб із міста Запоріжжя та 78 - із сільської місцевості.

Критерії включення: пацієнти чоловічої та жіночої статі віком від 45 до 70 років; рецидив пароксизмальної фібриляції передсердь; верифікована стабільна IXC поєднана з гіпертонічною хворобою II стадії з відомою тривалістю захворювання більше 1 року; згода пацієнта на участь у досліджені.

Критерії виключення: атріовентрикулярна блокада II-ІІІ ступеня; шлуночкові аритмії; недостатність кровообігу більш II класу NYHA; онкологічні захворювання; порушення функції щитоподібної залози; цукровий діабет; гемодинамічно значущі вади серця; наркоманія, алкогольна залежність, наявність психічних розладів; відмова пацієнта від подальшого спостереження.

Скринінг та розподіл хворих на групи. Верифікацію діагнозу пароксизмальної форми фібриляції передсердь проводили згідно з рекомендаціями лікування ФП Європейського товариства кардіологів 2016 року [11]. Наявність ФП визначали шляхом реєстрації ЕКГ змін у пацієнта при обстеженні. Розподіл хворих на групи проводили після встановлення відповідності хворих щодо критеріїв включення/виключення дослідження залежно від комбінації генотипу поліморфізмів генів.
Ехокардіографія. Ехокардіографічне ультразвукове дослідження серця проводили усім хворим після відновлення синусового ритму на апараті "MyLabSeven" у M- та B-режимах за стандартною методикою, за допомогою конвексного датчика з частотою локації 1-5 МГц. Визначали наступні параметри: кінцевий діастолічний розмір (КДР), товщину міжшлуночкової перетинки (ТМШП) у діастолу, товщину задньої стінки лівого шлуночка (ТЗС ЛШ) у діастолу. Визначали масу міокарда ЛШ (ММЛШ) за формулою ASE (The American Society of Echocardiography) і розраховували індекс ММЛШ (ІММЛШ). Після розрахунку відносної товщини стінки ЛШ (ВТС) аналізували ІММЛШ, окремо для жінок і чоловіків, використовуючи гендерні норми. Визначення гіпертрофії лівого шлуночка проводили на основі клінічних рекомендаціях Європейського товариства кардіологів, згідно класифікації [12].

Визначення поліморфізму генів проводили за допомогою полімеразної ланцюгової реакції (ПЛР). Геномну ДНК виділяли з лейкоцитів периферичної крові за допомогою стандартної тест-системи «ДНК-експрес-кров» (Літех, Росія) відповідно до інструкції виробника. Визначення SNP (Single Nucleotide Polymorphism) поліморфізмів A1166C у гені рецептора першого типу до ангіотензину II (AGTR1) і Т174М в ангіотензиногені (AGT) проводили методом ПЛР у режимі реального часу з використанням ампліфікатору "Rotor-Gene 6000" (Corbett Research, Australia). Використовували структуру праймерів зі стандартних наборів «SNP-експресPВ» (Літех).

Статистична обробка отриманих результатів. Отримані дані представлені у вигляді медіани і міжквартильного діапазону $\mathrm{Me}\left[\mathrm{Q}_{25} ; \mathrm{Q}_{75}\right]$, 6о мали розподіл відмінний від нормального. Результати дослідження оброблені методами параметричної або непараметричної статистики в залежності від розподілу вибірки, за допомогою спеціалізованих комп'ютерних прикладних програм ApacheOpenOffice (version 4.1) i PSPP (version 0.10.2, GNU Project, 1998-2016). При параметричному розподілі для порівняння двох незалежних вибірок застосовували непарний критерій Стьюдента (t-критерій), непараметричний метод Манна-Уітні (U-критерій) застосовували при розподілі, відмінному від нормального. Відмінності між порівнюваними вибірковими сукупностями визнавали достовірними при рівні статистичної значимості нижче $0,05(p<0,05)$, що $є$ загальноприйнятим у медико-біологічних дослідженнях. Розраховували відносний ризик (ВР) та його 95 \% довірчий інтервал (ДІ), як відношення частоти випадків серед пацієнтів, що піддалися впливу досліджуваного фактора до частоти випадків серед 
Огляди літератури, оригінальні дослідження, погляд на проблему, випадок з практики, короткі повідомлення досліджуваних, на яких цей фактор не вплинув. Достовірним вважали значення 95 \% ДІ ВР, що не перетинало 1.

Результати дослідження та їх обговорення. Визначали демографічні характеристики обстежених пацієнтів. Дані про тривалість IXC та ГX були отримані у ході збору анамнезу, а також на підставі записів в амбулаторних картах. Значення індексу маси тіла (IMT), систолічного і діастолічного артеріального тиску (САТ і ДАТ) оцінювали при скринінгу пацієнтів. Отримані дані представлені у таблиці 1.

Таблиця 1. Демографічна характеристика пацієнтів (Ме [25; 75], n=176)

\begin{tabular}{|c|c|c|c|c|c|c|}
\hline \multirow{3}{*}{$\begin{array}{c}\text { Показник, } \\
\text { одиниця } \\
\text { вимірювання }\end{array}$} & \multicolumn{2}{|c|}{$\begin{array}{c}\text { Поліморфізм A1166C гену } \\
\text { AGTR1 }\end{array}$} & \multirow{3}{*}{$\begin{array}{l}\frac{0}{1} \\
\grave{0} \\
. \frac{0}{\alpha} \\
\grave{a}\end{array}$} & \multicolumn{2}{|c|}{ Поліморфізм T174M гену АGT } & \multirow{3}{*}{$\begin{array}{l}\frac{0}{1} \\
\grave{d} \\
\frac{0}{\alpha} \\
\dot{a}\end{array}$} \\
\hline & $\begin{array}{c}\text { AA } \\
(n=75)\end{array}$ & $\begin{array}{c}A C+C C \\
(n=101)\end{array}$ & & $\begin{array}{c}\text { TT } \\
(n=85)\end{array}$ & $\begin{array}{c}\mathrm{TM}+\mathrm{MM} \\
(\mathrm{n}=91)\end{array}$ & \\
\hline & 1 & 2 & & 3 & 4 & \\
\hline Вік, років & $\begin{array}{c}61,0 \\
{[54,0 ; 65,0]} \\
\end{array}$ & $\begin{array}{c}61,0 \\
{[56,0 ; 64,0]} \\
\end{array}$ & $P_{1-2}=0,82$ & $\begin{array}{c}62,0 \\
{[56,0 ; 65,0]}\end{array}$ & $\begin{array}{c}61,0 \\
{[55,0 ; 64,0]}\end{array}$ & $P_{3-4}=0,21$ \\
\hline $\begin{array}{l}\mathrm{IMT} \\
\mathrm{K \Gamma} / \mathrm{M}^{2}\end{array}$ & $\begin{array}{c}27,5 \\
{[26,1 ; 31,1]}\end{array}$ & $\begin{array}{c}28,0 \\
{[26,5 ; 33,1]}\end{array}$ & $P_{1-2}=0,16$ & $\begin{array}{c}27,7 \\
{[26,5 ; 31,1]}\end{array}$ & $\begin{array}{c}28,0 \\
{[26,4 ; 31,3]}\end{array}$ & $P_{3-4}=0,44$ \\
\hline $\begin{array}{l}\text { САТ, } \\
\text { Мм рт. ст. }\end{array}$ & $\begin{array}{c}140,0 \\
{[120,0 ; 160,0]}\end{array}$ & $\begin{array}{c}140,0 \\
{[130,0 ; 150,0]}\end{array}$ & $P_{1-2}=0,73$ & $\begin{array}{c}140,0 \\
{[130,0 ; 150,0]}\end{array}$ & $\begin{array}{c}140,0 \\
{[130,0 ; 150,0]}\end{array}$ & $P_{3-4}=0,75$ \\
\hline $\begin{array}{l}\text { ДАТ, } \\
\text { мм рт. ст. }\end{array}$ & $\begin{array}{c}80,0 \\
{[80,0 ; 90,0]}\end{array}$ & $\begin{array}{c}80,0 \\
{[80,0 ; 90,0]}\end{array}$ & $p_{1-2}=0,96$ & $\begin{array}{c}80,0 \\
{[80,0 ; 90,0]}\end{array}$ & $\begin{array}{c}80,0 \\
{[80,0 ; 90,0]}\end{array}$ & $P_{3-4}=0,88$ \\
\hline IXC, років & $\begin{array}{c}2,0 \\
{[1,0 ; 3,0]}\end{array}$ & $\begin{array}{c}2,0 \\
{[1,0 ; 4,0]}\end{array}$ & $p_{1-2}=0,18$ & $\begin{array}{c}2,0 \\
{[1,0 ; 3,0]}\end{array}$ & $\begin{array}{c}2,0 \\
{[1,0 ; 3,0]}\end{array}$ & $P_{3-4}=0,63$ \\
\hline ГХ, років & $\begin{array}{c}7,0 \\
{[3,0 ; 12,0]}\end{array}$ & $\begin{array}{c}10,0 \\
{[4,0 ; 12,0]}\end{array}$ & $P_{1-2}=0,33$ & $\begin{array}{c}7,0 \\
{[3,0 ; 10,0]}\end{array}$ & $\begin{array}{c}10,0 \\
{[4,0 ; 14,0]}\end{array}$ & $P_{3-4}=0,23$ \\
\hline
\end{tabular}

Усі 176 обстежених осіб були порівняні за віком і соціальним статусом. Медіана величини IMT у групі AА поліморфізму A1166C була 27,5 [26,1; 31,1] кг/M², систолічного артеріального тиску 140,0 [120,0; 160,0] мм рт. ст. і діастолічного артеріального тиску - 80,0 [80,0; 90,0] мм рт. ст. Тривалість IXC склала 2,0 [1,0; 3,0] роки, гіпертонічної хвороби - 7,0 [3,0; 12,0] років. У групі АC+СС поліморфізму А1166C медіана величини IMT склала 28,0 $[26,5 ; 33,1] \mathrm{\kappa г} / \mathrm{M}^{2}$, САТ - 40,0 [130,0; 150,0] мм рт. ст. і ДАТ - 80,0 [80,0; 90,0] мм рт. ст. Анамнез захворювання IXC склав 2,0 [1,0; 4,0] роки і ГX - 10,0 [4,0; $12,0]$ років. Групи були порівняні між собою за за
IMT, САТ, ДАТ, тривалістю IXC та ГX (p>0,05). Також за зазначеними показниками були зіставні між собою групи ТТ і ТМ+ММ поліморфізму Т174M.

Оцінювали показники ремоделювання лівого шлуночка у залежності від поліморфізмів A1166C гена AGTR1 та T174M гена AGT. Отримані дані представлені у таблиці 2.

Не було виявлено достовірних відмінностей між значеннями таких показників ремоделювання лівого шлуночка, як КДР ЛШ, ТМШП, ТЗС ЛШ, IММЛШ та ВТС ЛШ в залежності від генотипу поліморфізму A1166C гена AGTR1 (p>0,05). У групі пацієнтів генотипу ТМ+MМ поліморфізму T174M

Таблиця 2. Показники ремоделювання лівого шлуночка у залежності від поліморфізмів A1166C гена AGTR1 та T174M гена AGT (Me [25; 75], $\mathrm{n=186}$ )

\begin{tabular}{|c|c|c|c|c|c|c|}
\hline \multirow{3}{*}{$\begin{array}{c}\text { Показник, } \\
\text { одиниця } \\
\text { вимірювання }\end{array}$} & \multicolumn{2}{|c|}{$\begin{array}{c}\text { Поліморфізм A1166C гену } \\
\text { AGTR1 }\end{array}$} & \multirow{3}{*}{$\begin{array}{l}\frac{0}{1} \\
\stackrel{0}{1} \\
. \frac{9}{a} \\
a\end{array}$} & \multicolumn{2}{|c|}{ Поліморфізм T174M гену АGT } & \multirow{3}{*}{$\begin{array}{l}0 \\
\frac{1}{d} \\
\stackrel{m}{a} \\
\frac{1}{a}\end{array}$} \\
\hline & $\begin{array}{c}\mathrm{AA} \\
(\mathrm{n}=75)\end{array}$ & $\begin{array}{c}A C+C C \\
(n=101)\end{array}$ & & $\begin{array}{c}\text { TT } \\
(n=85)\end{array}$ & $\begin{array}{c}\mathrm{TM}+\mathrm{MM} \\
(\mathrm{n}=91)\end{array}$ & \\
\hline & 1 & 2 & & 3 & 4 & \\
\hline КДР ЛШ, см & $\begin{array}{c}5,08 \\
{[4,70 ; 5,52]}\end{array}$ & $\begin{array}{c}5,19 \\
{[4,75 ; 5,62]}\end{array}$ & $p_{1-2}=0,48$ & $\begin{array}{c}5,04 \\
{[4,75 ; 5,42]}\end{array}$ & $\begin{array}{c}5,31 \\
{[4,70 ; 5,62]}\end{array}$ & $P_{3-4}=0,38$ \\
\hline ТМШП, см & $\begin{array}{c}1,09 \\
{[1,01 ; 1,19]}\end{array}$ & $\begin{array}{c}1,12 \\
{[1,06 ; 1,21]}\end{array}$ & $P_{1-2}=0,14$ & $\begin{array}{c}1,09 \\
{[1,02 ; 1,20]}\end{array}$ & $\begin{array}{c}1,13 \\
{[1,05 ; 1,20]}\end{array}$ & $\mathrm{P}_{3-4}=0,15$ \\
\hline ТЗС ЛШ, см & $\begin{array}{c}1,12 \\
{[1,01 ; 1,22]}\end{array}$ & $\begin{array}{c}1,15 \\
{[1,08 ; 1,22]}\end{array}$ & $p_{1-2}=0,16$ & $\begin{array}{c}1,12 \\
{[1,01 ; 1,19]}\end{array}$ & $\begin{array}{c}1,17 \\
{[1,08 ; 1,24]}\end{array}$ & $P_{3-4}=0,02$ \\
\hline IММЛШ, г/M² & $\begin{array}{c}115,91 \\
{[93,59 ; 135,53]}\end{array}$ & \begin{tabular}{|c|}
122,34 \\
{$[99,51 ; 141,08]$} \\
\end{tabular} & $p_{1-2}=0,22$ & $\begin{array}{c}114,60 \\
{[97,41 ; 131,24]}\end{array}$ & $\begin{array}{c}125,92 \\
{[96,32 ; 146,30]}\end{array}$ & $P_{3-4}=0,04$ \\
\hline ВТС ЛШ & $\begin{array}{c}0,43 \\
{[0,40 ; 0,50]}\end{array}$ & $\begin{array}{c}0,44 \\
{[0,41 ; 0,49]}\end{array}$ & $P_{1-2}=0,33$ & $\begin{array}{c}0,43 \\
{[0,40 ; 0,46]}\end{array}$ & $0,44[0,41 ; 0,50]$ & $P_{3-4}=0,22$ \\
\hline
\end{tabular}


Огляди літератури, оригінальні дослідження, погляд на проблему, випадок з практики, короткі повідомлення гену AGT достовірно відзначався більший IММЛШ $125,92[96,32 ; 146,30]$ г/м² проти 114,60 [97,41; $131,24]$ г/м² групи генотип ТT, (р<0,05). Також достовірним було збільшення значення ТЗС ЛШ $1,17[1,08 ; 1,24]$ см у групі генотипу TM+ММ ніж $1,12[1,01 ; 1,19]$ см у групі генотипу TT, $(p<0,05)$. Інші показники ремоделювання лівого шлуночка у залежності від генотипу поліморфізму Т174М

гена AGT були зіставні, хоча слід зазначити, що була тенденція до їх збільшення у групі генотипу $\mathrm{TM}+\mathrm{MM}$.

3 метою оцінки внеску поліморфізму генів у формування ремоделювання лівого шлуночка всі пацієнти були розділені на 2 групи у залежності від наявності або відсутності глШ. Отримані результати представлені у таблиці 3.

Таблиця 3. Ризики ремоделювання лівого шлуночка у залежності від поліморфізмів генів

\begin{tabular}{|c|c|c|c|}
\hline Комбінація генотипу & Ремоделювання ЛШ & BP & 95 \% ДІ ВР \\
\hline $\begin{array}{l}A A(n=75) / \\
A C+C C(n=101)\end{array}$ & Усі типи разом & 1,260 & $1,094-1,450$ \\
\hline $\begin{array}{l}\text { TT }(n=85) / \\
\text { TM+MM (n=91) }\end{array}$ & Усі типи разом & 1,203 & $1,060-1,365$ \\
\hline $\begin{array}{l}\mathrm{AA}(\mathrm{n}=38) / \\
\mathrm{AC}+\mathrm{CC}(\mathrm{n}=34)\end{array}$ & Ексцентрична гіпертрофія & 1,647 & $1,156-2,347$ \\
\hline $\begin{array}{l}\text { TT }(n=41) / \\
\text { TM+MM }(n=31)\end{array}$ & Ексцентрична гіпертрофія & 1,503 & $1,078-2,096$ \\
\hline $\begin{array}{l}A A(n=49) / \\
A C+C C(n=49)\end{array}$ & Концентрична гіпертрофія & 1,495 & $1,148-1,947$ \\
\hline $\begin{array}{l}\text { TT }(n=49) / \\
\text { TM+MM }(n=46)\end{array}$ & Концентрична гіпертрофія & 1,420 & $1,107-1,823$ \\
\hline $\begin{array}{l}\mathrm{AA}(\mathrm{n}=31) / \\
\mathrm{AC}+\mathrm{CC}(\mathrm{n}=28)\end{array}$ & Концентричне ремоделювання & 2,030 & $1,252-3,291$ \\
\hline $\begin{array}{l}\text { TT }(n=35) / \\
\text { TM+MM }(n=24)\end{array}$ & Концентричне ремоделювання & 1,641 & $1,069-2,519$ \\
\hline
\end{tabular}

У групі АА поліморфізму А1166С із 75 осіб - 19 пацієнтів були з нормальною моделлю лш i 56 хворих мали Глш, у групі АС+CС із 101 особи 6 пацієнтів були з нормальною моделлю лШ i 95 хворих мали ГЛШ, ВР щодо ремоделювання ЛШ склав 1,260, ДІ ВР 1,094-1,450. 385 осіб групи ТТ поліморфізму Т174М - 19 пацієнтів були з нормальною моделлю лШ і 66 хворих мали ГлШ, у групі ТМ+ММ із 91 особи - 6 пацієнтів були з нормальною моделлю ЛШ і 85 хворих мали ГЛШ, ВР щодо ремоделювання ЛШ склав 1,203, ДІ ВР 1,060-1,365. Найбільшим виявився ВР 2,030, ДІ ВР1,252-3,291 щодо концентричного ремоделювання для поліморфізму A1166C гена AGTR1.

Останнім часом визначається високий інтерес дослідників до поліморфізму генів білків РАAC, що є логічним оскільки роль цієї системи у формуванні та прогресуванні ГлШ надзвичайно велика. Поліморфізми Т174М гена ангіотензиногену і A1166C гена рецептора 1 типу до ангіотензину активно вивчаються в останні роки, тому що вони впливають на розвиток серцево-судинних захворювань [13].

У результаті проведеного нами дослідження встановлено, що показники ремоделювання лівого шлуночка для поліморфізму Т174М достовірно розрізняються, в той час як статистично значущих відмінностей для поліморфізму А1166C не виявлено. Однак слід зазначити, що ті відмінності, які ми спостерігали на рівні тенденції, можуть досягти статистично значущого рівня при збільшенні обсягу досліджуваної вибірки.

Дані літератури з генетичних досліджень, які присвячені виявленню зв'язку поліморфізму генів компонентів РААС з розвитком ГЛШ все ще нечисленні і нерідко суперечливі, істотно різняться в окремих популяціях. Так за результатами дослідження G.D. Kobalava et al. поліморфізму T174M гена AGT виявили асоціацію М-алеля з гіпертрофією лівого шлуночка у хворих на артеріальну гіпертензію [14], тоді як за даними Z. Junli et al. не має асоціацій між генотипом T174M з наявністю глШ [15].

Суперечливі дані представлені у літературі і про вплив поліморфізму A1166C гена AGTR1 на розвиток ГЛШ. У роботі Y. Jin et al. виявлена сильна достовірна асоціація генотипу С/C і структурних змін серця [16]. Тоді як у американців різних етнічних груп подібної закономірності не встановлено [17].

Відмінності в результатах цих досліджень можуть бути обумовлені різними критеріями відбору пацієнтів і контрольної групи. Більш того, результати цих досліджень відрізняються один від одного тим, що вони проводяться з різними расами і популяціями. 
Огляди літератури, оригінальні дослідження, погляд на проблему, випадок з практики, короткі повідомлення

Таким чином, при дослідженні впливу даних поліморфізмів на діяльність серцево-судинної системи слід враховувати генетичні особливості окремих етносів і популяцій. Отримані нами результати дозволяють вважати поліморфізми генів додатковим фактором прогнозу формування неадекватної маси лівого шлуночка, що веде до його несприятливого ремоделювання.

Хоча в даний час генетичне тестування в рутинній клінічній практиці не використовується, але В майбутньому геномний аналіз може дати можливість вдосконалити протокол ведення пацієнтів з ФП. Ідентифікація поліморфізмів генів, асоційованих з ФП, дозволить нам отримати інформацію про основі механізмів сприйнятливості до цього захворювання. У найближчі роки ми очікуємо, що додавання тестування на рівні геному і складних аналізів геномного та екологічного ризику буде сприяти подальшому вдосконаленню індивідуальних підходів до ведення пацієнтів з ФП. Для того що6 мати можливість пояснити патогенез ФП і розробити відповідні методи лікування цього захворювання, необхідно у подальшому провести комплексні дослідження з різними популяціями із великою кількістю пацієнтів.

Висновки. 1. Генетичні поліморфізми ренінангіотензин-альдостеронової системи можуть впливати на вираженість патологічних змін у хворих на пароксизмальну ФП на тлі IXC з гіпертонічною хворобою.

2. Визначено, що поліморфізм Т174М гена ангіотензиногену впливає на показники ремоделювання лівого шлуночка. У пацієнтів, що мали алельний ген М індекс маси міокарда лівого шлуночка був достовірно вище.

3. Дослідження поліморфізму А1166C гена AGTR1 дозволяє прогнозувати ризик виникнення несприятливого концентричного ремоделювання лівого шлуночка, при наявності у хворого алельного гену С збільшується ризик 2,03 у рази.

Перспективи подальших досліджень. Стає очевидною необхідність проведення подальших поглиблених досліджень у цьому напрямку для розробки персоналізованого підходу до вибору лікарських засобів у хворих з персистуючою ФП на тлі IXC з гіпертонічною хворобою, що забезпечить прицільну корекцію патогенетичних процесів з урахуванням генотипових особливостей пацієнта. Створення комплексу лікувальних і профілактичних заходів на основі індивідуальних характеристик пацієнта складає основу персоналізованої медицини, на сьогодні нового напрямку медицини, який успішно розвивається.

\section{ЛITEPAТУРА}

1. 2019 AHA/ACC/HRS focused update of the 2014 AHA/ACC/HRS guideline for the management of patients with atrial fibrillation: a report of the American College of Cardiology/American Heart Association Task Force on Clinical Practice Guidelines and the Heart Rhythm Society / C. T. January, L. S. Wann, H. Calkins [et al.] // J. Am. Coll. Cardiol. - 2019. - Vol. 74 (1). - P. 104-132.

2. Epidemiology of atrial fibrillation in the 21st century: novel methods and new insights / J. Kornej, C. S. Börschel, E. J. Benjamin [et al.] // Circ. Res. - 2020. Vol. 127 (1). - P. 4-20.

3. Tucker N. R. Common variation in atrial fibrillation: navigating the path from genetic association to mechanism / N. R. Tucker, S. Clauss, P. T. Ellinor // Cardiovasc. Res. 2016. - Vol. 109 (4). - P. 493-501.

4. Kokubo, Y. Traditional cardiovascular risk factors for incident atrial fibrillation / Y. Kokubo, C. Matsumoto // Circ. J. - 2016. - Vol. 80. - Issue 12. - P. 2415-2422.

5. Multi-ethnic genome-wide association study for atrial fibrillation / C. Roselli, M. D. Chaffin, L. Weng [et al.] // Nat. Genet.-2018.-Vol. 50 (9).-P.1225-1233. DOI:10.1038/ s41588-018-0133-9.

6. Atrial fibrillation and hypertension / M. S. Dzeshka, A. Shantsila, E. Shantsila [et al.] // Hypertens. - 2017. - Vol. 70 (5). - P. 854-861. DOI: 10.1161/hypertensionaha.117.08934.

7. Angiotensinogen and ACE gene polymorphisms and risk of atrial fibrillation in the general population /

L. S. Ravn, M. Benn, B. G. Nordestgaard [et al.] // Pharmacogenet. Genomics. - 2008. - Vol. 18 (6). - P. 525-533.

8. Angiotensinogen (AGT) M235T, AGT T174M and angiotensin-1-converting enzyme (ACE) I/D gene polymorphisms in essential hypertension: effects on ramipril efficacy / V. Kolovou, E. Lagou, C. Mihas [et al.] // Open Cardiovasc. Med. J. - 2015. - Vol. 9. - P. 118.

9. Association of left ventricular mass with the AGTR1 A1166C polymorphism / Y. Jin, T. Kuznetsova, L. Thijs [et al.] // Am. J. Hypertens. - 2012. - Vol. 25 (4). - P. 472-478.

10. The interrelationship of bone and cardiovascular remodeling biomarkers and clinical peculiarities of coronary artery disease in postmenopausal women / N. S. Mykhailovska, I. O. Stetsiuk, T. O. Kulynych // Reumatologia. - 2020. Vol. 58 (3). - P. 142-149. DOI: 10.5114/reum.2020.96687.

11. 2016 ESC Guidelines for the management of atrial fibrillation developed in collaboration with EACTS / P. Kirchhof, S. Benussi, D. Kotecha [et al.] // Eur. Heart J. - 2016. Vol. 37 (38). - P. 2893-2962.

12. Recommendations on the use of echocardiography in adult hypertension: a report from the European Association of Cardiovascular Imaging (EACVI) and the American Society of Echocardiography (ASE) / T. H. Marwick, T. C. Gillebert, G. Aurigemma [et al.] // Eur. Heart J. Cardiovasc. Imaging. - 2015. - Vol. 16 (6). - P. 577-605.

13. Association of beta (1)-adrenergic receptor gene polymorphisms with left ventricular hypertrophy in human 
Огляди літератури, оригінальні дослідження, поглядн essential hypertension / C. Fu, H. Wang, S. Wang [et al.] // Clin. Biochem. - 2008. - Vol. 41 (10-11). - P. 773-778.

14. Kobalava G. D. Clinico-genetics determinants of left ventricular hypertrophy in patients with arterial hypertension / G. D. Kobalava, U. V. Kotovskaya, D. A. Chistiakov // Cardiol. - 2001. - Vol. 41 (7). - P. 39-44.

15. Association between the M235T, T174M polymorphism of the angiotensinogen gene and left ventricular hypertrophy in essential hypertension in Kazakans / Z. Junli, L. Nanfang, Z. Delian [et al.] // Heart. - 2010. - Vol. 96 лгму, випадок з практики, короткі повідомлення (Suppl. 3). - P. A9-A9.

16. Association of left ventricular mass with the AGTR1 A1166C polymorphism / Y. Jin, T. Kuznetsova, L. Thijs [et al.] // Am. J. Hypertens. - 2012. - Vol. 25 (4). - P. 472-478. DOI:10.1038/ajh. 2011.244.

17. Effects of angiotensinogen and angiotensin II type I receptor genes on blood pressure and left ventricular mass trajectories in multiethnic youth / X. Wang, $\mathrm{H}$. Zhu, Y. Dong [et al.] // Twin Res. Hum. Genet. - 2006. - Vol. 9 (3). P. 393-402.

\section{REFERENCES}

1. January, C.T., Wann, L.S., Calkins, H., Chen, L.Y., Cigarroa, J.E., Cleveland, J.C., ..., \& Heidenreich, P.A. (2019). 2019 AHA/ACC/HRS focused update of the 2014 AHA/ ACC/HRS guideline for the management of patients with atrial fibrillation: a report of the American College of Cardiology/American Heart Association Task Force on Clinical Practice Guidelines and the Heart Rhythm Society. J. Am. Coll. Cardiol., 74 (1), 104-132.

2. Kornej, J., Börschel, C.S., Benjamin, E.J., \& Schnabel, R.B. (2020). Epidemiology of atrial fibrillation in the 21st century: novel methods and new insights. Circ. Res., 127 (1), 4-20.

3. Tucker, N.R., Clauss, S., \& Ellinor, P.T. (2016). Common variation in atrial fibrillation: navigating the path from genetic association to mechanism. Cardiovasc. Res., 109 (4), 493-501.

4. Kokubo, Y., \& Matsumoto, C. (2016). Traditional cardiovascular risk factors for incident atrial fibrillation. Circ. J., 80, 12, 2415-2422. DOI:10.1253/circj.CJ-16-0919.

5. Roselli, C., Chaffin, M.D., Weng, L., Aeschbacher, S., Ahlberg, G., Albert, C.M., ..., \& Ellinor, P.T. (2018). Multiethnic genome-wide association study for atrial fibrillation. Nat. Genet., 50 (9), 1225-1233. DOI:10.1038/s41588018-0133-9.

6. Dzeshka, M.S., Shantsila, A., Shantsila, E., \& Lip, G.Y. (2017). Atrial fibrillation and hypertension. Hypertens., 70 (5), 854-861. DOI: 10.1161/hypertensionaha.117.08934.

7. Ravn, L.S., Benn, M., Nordestgaard, B.G., Sethi, A.A., Agerholm-Larsen, B., Jensen, G.B., \& Tybjærg-Hansen, A. (2008). Angiotensinogen and ACE gene polymorphisms and risk of atrial fibrillation in the general population. Pharmacogenet. Genomics., 18 (6), 525-533.

8. Kolovou, V., Lagou, E., Mihas, C., Vasiliki, G., Katsiki, N., Kollia, A., ... \& Kolovou, G. (2015). Angiotensinogen (AGT) M235T, AGT T174M and angiotensin-1-converting enzyme (ACE) I/D gene polymorphisms in essential hypertension: effects on ramipril efficacy. Open Cardiovasc. Med. J., 9, 118.

9. Jin, Y., Kuznetsova, T., Thijs, L., Schmitz, B., Liu, Y., Asayama, K., ..., \& Staessen, J. A. (2012). Association of left ventricular mass with the AGTR1 A1166C polymorphism. Am. J. Hypertens., 25 (4), 472-478.

10. Mykhailovska, N.S., Stetsiuk, I.O., Kulynych, T.O., Gorbachova, S.V., \& Zhulkevych, I.V. (2020). The interrelationship of bone and cardiovascular remodeling biomarkers and clinical peculiarities of coronary artery disease in postmenopausal women. Reumatologia, 58 (3), 142-149. doi: 10.5114/reum.2020.96687.

11. Kirchhof, P., Benussi, S., Kotecha, D., Ahlsson, A., Atar, D., Casadei, B., ..., \& Hindricks, G. (2016). 2016 ESC Guidelines for the management of atrial fibrillation developed in collaboration with EACTS. Eur. Heart J., 37 (38), 2893-2962.

12. Marwick, T.H., Gillebert, T.C., Aurigemma, G., Chirinos, J., Derumeaux, G., Galderisi, M., ..., \& Senior, R. (2015). Recommendations on the use of echocardiography in adult hypertension: a report from the European Association of Cardiovascular Imaging (EACVI) and the American Society of Echocardiography (ASE). Eur. Heart J. Cardiovasc. Imaging, 16 (6), 577-605.

13. Fu, C., Wang, H., Wang, S., Shi, Y., Zhou, X., Sun, K., ..., \& Hui, R. (2008). Association of beta (1)-adrenergic receptor gene polymorphisms with left ventricular hypertrophy in human essential hypertension. Clin. Biochem., 41 (10-11), 773-778.

14. Kobalava, G.D., Kotovskaya, U.V., \& Chistiakov, D.A. (2001). Clinico-genetics determinants of left ventricular hypertrophy in patients with arterial hypertension. Cardiol., 41 (7), 39-44.

15. Junli, Z., Nanfang, L., Delian, Z., Ling, Z., \& Tao, L. (2010). e0026 Association between the M235T, T174M polymorphism of the angiotensinogen gene and left ventricular hypertrophy in essential hypertension in Kazakans. Heart, 96 (Suppl. 3), A9-A9.

16. Jin, Y., Kuznetsova, T., Thijs, L., Schmitz, B., Liu, Y., Asayama, K., ..., \& Staessen, J.A. (2012). Association of left ventricular mass with the AGTR1 A1166C polymorphism. Am. J. Hypertens., 25 (4), 472-478. DOI:10.1038/ajh. 2011.244.

17. Wang, X., Zhu, H., Dong, Y., Treiber, F.A., \& Snieder, H. (2006). Effects of angiotensinogen and angiotensin II type I receptor genes on blood pressure and left ventricular mass trajectories in multiethnic youth. Twin Res. Hum. Genet., 9 (3), 393-402. 


\title{
Огляди літератури, оригінальні дослідження, погляд на проблему, випадок з практики, короткі повідомлення РЕМОДЕЛИРОВАНИЕ ЛЕВОГО ЖЕЛУДОЧКА У ПАЦИЕНТОВ С ПАРОКСИЗМАЛЬНОЙ ФИБРИЛЛЯЦИЕЙ ПРЕДСЕРДИЙ ПРИ ПОЛИМОРФИЗМАХ ГЕНОВ РЕНИН-АНГИОТЕНЗИН-АЛЬДОСТЕРОНОВОЙ СИСТЕМЫ
}

\author{
○И. М. Фуштей, С. Г. Подлужный, Е. В. Сидь \\ Государственное заведение «Запорожская медицинская академия последипломного образования \\ министерства здравоохранения Украины»
}

РЕзюмЕ. Современными важными медико-социальными проблемами в мире являются гипертоническая болезнь (ГБ), ишемическая болезнь сердца (ИБС) и фибрилляция предсердий (ФП). Возникновению аритмий может способствовать сочетание определенных полиморфизмов генов, особенно актуальным является изучение роли генов ренин-ангиотензин-(РАAC), поскольку в настоящее время, именно ее роль, в патогенезе ФП соединенной с ГБ определяется как ведущая. В настоящее время является ограниченное количество данных о связи ГлЖ у пациентов с коморбидной патологией, указывает на необходимость определения популяционных особенностей при изучении роли полиморфизмов генов в развитии мультифакторных заболеваний таких, как ИБС и ГБ и их осложнений, вызывает большой практический интерес.

Цель исследования. Определить особенности ремоделирования левого желудочка у пациентов с пароксизмальной фибрилляцией предсердий при полиморфизме генов ренин-ангиотензин-альдостероновой системы.

Материалы и методы. Для достижения цели было проведено проспективное, открытое сравнительное исследование на базе коммунального некоммерческого предприятия «Городская больница № 10» Запорожского городского совета. Выборку пациентов проводили в период с 2014 по 2019 г. Результаты исследования основаны на данных комплексного обследования и динамического наблюдения за 176 больными пароксизмальной ФП на фоне ИБС с гипертонической болезнью, из них было 98 человек из города Запорожья и 78 - из сельской местности. Распределение больных группы проводили после установления соответствия больных относительно критериев включения/выключения исследования и в зависимости от комбинации генотипа полиморфизмов генов. Всем обследованным было выполнено эхокардиографическое исследование, определение полиморфизма генов.

Полученные результаты. Было обнаружено, что генетические полиморфизмы ренин-ангиотензин могут влиять на выраженность патологических изменений у больных пароксизмальной ФП на фоне ИБС с гипертонической болезнью. Определено, что полиморфизм Т174М гена ангиотензиногена влияет на показатели ремоделирования левого желудочка. У пациентов, которые имели аллельный ген М, индекс массы миокарда левого желудочка был достоверно выше. Исследование полиморфизма A1166C гена AGTR1 позволяет прогнозировать риск возникновения неблагоприятного концентрического ремоделирования левого желудочка, при наличии у больного аллельного гена С увеличивается риск в 2,03 раза.

Выводы. Таким образом, при исследовании влияния данных полиморфизмов на деятельность сердечно-сосудистой системы следует учитывать генетические особенности отдельных этносов и популяций. Полученные нами результаты позволяют считать полиморфизмы генов дополнительным фактором прогноза формирования неадекватной массы левого желудочка, что ведет к его неблагоприятному ремоделированию.

КЛюЧЕВЫЕ СЛОВА: ремоделирование сердца; ренин-ангиотензин-альдостероновая система; ген; фибрилляция предсердий; эхокардиография.

\section{THE LEFT VENTRICULAR REMODELING AMONG PATIENTS WITH PAROXYSMAL ATRIAL FIBRILLATION BY GENE POLYMORPHISMS RENIN-ANGIOTENSIN-ALDOSTERONE SYSTEM}

\author{
○I. M. Fushtey, S. G. Podluzhnyi, E. V. Sid \\ Zaporizhzhia Medical Academy of Postgraduate Education
}

SUMMARY. Modern important medical and social problems in the world are hypertension, coronary heart disease (CHD) and atrial fibrillation (AF). Gene polymorphisms can contribute to the occurrence of arrhythmias, especially the study of the role of genes of the renin-angiotensin-aldosterone system (RAAS), because at present, its role in the pathogenesis of AF combined with hypertension is defined as leading. Currently, there is limited data on the relationship of left ventricular hypertrophy among patients with comorbid pathology, which indicates the need to determine population characteristics in studying the role of gene polymorphisms in the development of multifactorial diseases such as CHD and hypertension and their complications, which induces a great practical interest.

The aim of the study - to determine the features of left ventricular remodeling in patients with paroxysmal atrial fibrillation with gene polymorphisms of the renin-angiotensin-aldosterone system.

Material and Methods. To achieve this goal, a prospective, open comparative study was conducted on the basis of the City Hospital No. 10 of Zaporizhia City Council. The sample of patients was conducted in the period from 2014 to 2019. The results of the study are based on data from a comprehensive examination and dynamic monitoring of 176 patients with paroxysmal AF on the background of coronary heart disease and hypertension, of whom 98 were from Zaporizhzhia and 78 were from rural areas. The division of patients into groups was performed after establishing the compli- 
Огляди літератури, оригінальні дослідження, погляд на проблему, випадок з практики, короткі повідомлення ance of patients with the inclusion/exclusion criteria of the study depending on the combination of the genotype of gene polymorphisms. All subjects underwent echocardiographic examination, determination of gene polymorphism.

Results. It was found that genetic polymorphisms of the renin-angiotensin-aldosterone system can affect the severity of pathological changes in patients with paroxysmal AF on the background of coronary heart disease and hypertension. It was determined that the T174M polymorphism of the angiotensinogen gene affects the indicators of left ventricular remodeling. In patients with allelic gene $M$, the left ventricular myocardial mass index was significantly higher. The study of A1166C polymorphism of the AGTR1 gene allows to predict the risk of adverse concentric remodeling of the left ventricle, in the presence of a patient with the allelic gene $\mathrm{C}$ increases the risk by 2.03 times.

Conclusions. Thus, studying the influence of these polymorphisms on the activity of the cardiovascular system should take into account the genetic characteristics of individual ethnic groups and populations. The obtained results allow us to consider gene polymorphisms as an additional factor in predicting the formation of inadequate left ventricular mass, which leads to its unfavorable remodeling.

KEY WORDS: heart remodeling; renin-angiotensin-aldosterone system; gene; atrial fibrillation; echocardiography. 